\title{
Modulation of anti-tumor lymphocyte function by neurotransmitter glutamate
}

\author{
Thomas Hodo ${ }^{1}$, Menaka Thounaojam', Anil Shanker ${ }^{2 *}$ \\ From Society for Immunotherapy of Cancer 29th Annual Meeting \\ National Harbor, MD, USA. 6-9 November 2014
}

Most research to date pertaining to neural influence on immune response involves immunosuppression via the anti-inflammatory pathway. However, there is emerging evidence indicating that neurotransmitters have the ability to promote immune activation. We are investigating whether neurotransmitters can modulate and/or activate $\mathrm{T}$ cell function in situations where immunosuppression is prevalent such as in the tumor microenvironment. Published work suggests that glutamate, serotonin, dopamine, and Substance P trigger immune responses such as cytokine secretion, integrin expression, and chemotaxis. We saw that both CD4 and CD8 T cells express high surface protein levels of glutamate receptor AMPA iGluR3, which is able to import $\mathrm{Ca}^{2+}$ and $\mathrm{Na}+$. We also found that mGluR1 is significantly upregulated on lymphocytes upon activation. Our data further show that $\mathrm{T}$ cells in the tumor-draining LN and tumor-infiltrating lymphocytes have upregulated expression of iGluR3 and mGluR1. Treatment with glutamate or its receptor agonist augmented $\mathrm{T}$ cell proliferation following CD3-CD28-mediated TCR stimulation. Thus, modulation of glutamate receptor signaling can be useful for enhancing anti-tumor $\mathrm{T}$ cell immunity such as inhibition of AICD, enhancement of proliferation, and increased cytokine production $[1,2]$. Indeed, overactivation of lymphocytes in multiple sclerosis is closely tied to the overexpression of AMPA GluR3 on $\mathrm{T}$ cells [3]. Experiments are under way to dissect in an adoptive transfer set up whether glutamate-modulated immune effector function involves specific activation of anti-tumor lymphocytes to elicit cytolytic response that is needed to cause tumor cell death. Our findings will help identify novel neuro-immune modulators that may serve to enhance anti-tumor $\mathrm{T}$ cell response.

${ }^{2}$ Meharry Medical College School of Medicine / Vanderbilt-Ingram Cancer Center, Nashville, TN, United States

Full list of author information is available at the end of the article
Authors' details

'Meharry Medical College School of Medicine, Nashville, TN, United States. ${ }^{2}$ Meharry Medical College School of Medicine / Vanderbilt-Ingram Cancer Center, Nashville, TN, United States.

Published: 6 November 2014

\section{References}

1. Chiocchetti A, Miglio G, Mesturini R, Varsaldi F, Mocellin M, Orilieri E, Dianzani C, Fantozzi R, Dianzani U, Lombardi G: Group I mGlu receptor stimulation inhibits activation-induced cell death of human $T$ lymphocytes. British journal of pharmacology 2006, 148:760-768.

2. Pacheco R, Oliva H, Martinez-Navio JM, Climent N, Ciruela F, Gatell JM, Gallart T, Mallol J, Lluis C, Franco R: Glutamate released by dendritic cells as a novel modulator of T cell activation. J Immunol 2006, 177:6695-6704.

3. Sarchielli P, Di Filippo M, Candeliere A, Chiasserini D, Mattioni A, Tenaglia S, Bonucci M, Calabresi P: Expression of ionotropic glutamate receptor GLUR3 and effects of glutamate on MBP- and MOG-specific lymphocyte activation and chemotactic migration in multiple sclerosis patients. Journal of neuroimmunology 2007, 188:146-158.

doi:10.1186/2051-1426-2-S3-P38

Cite this article as: Hodo et al: Modulation of anti-tumor lymphocyte function by neurotransmitter glutamate. Journal for ImmunoTherapy of Cancer 2014 2(Suppl 3):P38.

Submit your next manuscript to BioMed Central and take full advantage of:

- Convenient online submission

- Thorough peer review

- No space constraints or color figure charges

- Immediate publication on acceptance

- Inclusion in PubMed, CAS, Scopus and Google Scholar

- Research which is freely available for redistribution 